This is an Accepted Manuscript of the article Latorre, S., \& Malo-Larrea, A. (2019). Policy-making Related Actors' Understandings About Nature-society Relationship: Beyond Modern Ontologies? The Case of Cuenca, Ecuador. Ecological Economics, 156, 387-396., available online

at:https://doi.org/10.1016/j.ecolecon.2018.10.017

(C2018. This manuscript version is made available under the CC-BY-NC-ND 4.0 license.

\title{
Policy-making related actors' understandings about nature-society relationship: beyond modern ontologies? The case of Cuenca, Ecuador.
}

\author{
Sara Latorre $a, *$, Antonio Malo-Larrea b,c \\ a Latin American Faculty of Social Sciences, FLACSO, Ecuador, La Pradera E7-174 y Av. Diego de \\ Almagro, Quito, Ecuador \\ b Institute for Environmental Science and Technology (ICTA), Universitat Autònoma de Barcelona \\ (UAB), Spain \\ c Catholic University of Cuenca, Center of Research, Innovation and Technology Transfer (CIIT)
}

\begin{abstract}
Over the last five decades the discursive debate on sustainability has reached prominence as the socio-ecological impacts of the human presence on Earth have grown rapidly. Nature discourses are interwoven with those of sustainability. Within this discursive field, a diverse set of competing discourses have emerged. Amongst the most radical ones, the discourse of Buen Vivir has recently gained relevance in Latin America. This position aims to depart from modern western ideologies, mainly those of nature-society dualism and Eurocentric universalism. In this study, the social perspectives about nature-society of subnational policy makers and other social actors involved in territorial planning in the city of Cuenca, Ecuador are examined. Four main social discourses are identified, which instead of breaking away from the society-nature divide, embrace it. Therefore, the case of Cuenca suggests that Ecuadorian citizens (including policy-makers) are still captured by the same discourses on nature-society belonging to the discursive field of modernity and its more contemporary corollaries: development and sustainable development. Hence, relational ontologies promoted by the discourse of Buen Vivir still do not resonate amongst Ecuadorian policy-related actors.
\end{abstract}

\section{Keywords}

Ecuador; Q-methodology; sustainability discourses; environmental politics; relational ontologies

\section{Introduction}

The discursive debate on sustainability has reached prominence over the last five decades as the socio-ecological impacts of the human presence on Earth have grown rapidly. Several scholars have mapped the contours of this debate pointing out the competing discourses that exist about the relationship between environment and development (Hajer;1997; Dryzek, 2013; Stevenson, 2015; Kothari et al., 2014; Gudynas, 2017; Hopwood et al., 2005; Lele, 
This is an Accepted Manuscript of the article Latorre, S., \& Malo-Larrea, A. (2019). Policy-making Related Actors' Understandings About Nature-society Relationship: Beyond Modern Ontologies? The Case of Cuenca, Ecuador. Ecological Economics, 156, 387-396., available online

at:https://doi.org/10.1016/j.ecolecon.2018.10.017

(02018. This manuscript version is made available under the CC-BY-NC-ND 4.0 license.

1991; Mels, 2009; Nygen, 1998; Rydin, 1999; Vanhulst and Beling, 2014; Faccer et al., 2014; Death, 2015; McManus, 1996; Ferguson, 2015; Adger et al., 2001; Connelly, 2007; Barry and Proops, 1999). Within this debate, several topics have been very recurrent, such as "the agents of change", "the means of transition", "the role of technology" and "the underlying ontological conceptions of the world", therefore nature discourses are internally interwoven with these sustainability discourses.

The modern conception of nature that emerged within the historical period called European modernity is particularly important for this case study (Castree, 2001). This understanding of nature was based on a dualist ontology that stressed the separation of nature from society. Furthermore, this vision observed the natural sphere as "natural resources" upon which humankind must rely and exploit in order to achieve its progress. Here, the ideal of progress is mostly understood in material terms as European urban society and ideals emerged as the benchmark to which different degrees of progress were compared.

These modern ideals of progress became universal through the invention of "underdevelopment" in the late 1940s and through modernization theory and practice (50-60s). This historical moment gave birth to the well-known discourse of development (Escobar, 1995; Ziai, 2007). This discourse relied on basic modern assumptions, such as economic growth, technological progress, industrialization, dualist ontologies, and linear material progress (Escobar, 1995; Gudynas, 2016; Villalba, 2013).

During the late 1960s and 1970s, this developmental discourse started to be questioned for its negative socio-environmental and economic impacts. Different intellectual currents raised sharp criticisms to it that led to the emergence of related terms such as human development, sustainable development, ethno-development, and endogenous development that can be seen as being part of the same discursive formation. None of these concepts questioned the core ideas of development and modernity such as the notions of progress, economic growth and the society-nature dual ontology. Following Gudynas (2016), it is believed that they are all different expressions of development within modernity. 
This is an Accepted Manuscript of the article Latorre, S., \& Malo-Larrea, A. (2019). Policy-making Related Actors' Understandings About Nature-society Relationship: Beyond Modern Ontologies? The Case of Cuenca, Ecuador. Ecological Economics, 156, 387-396., available online

at:https://doi.org/10.1016/j.ecolecon.2018.10.017

(C2018. This manuscript version is made available under the CC-BY-NC-ND 4.0 license.

Within these critiques to development, a group of scholars, well-known as postdevelopmental and post-colonial authors, sharpened their position, stating that they should stop searching for development alternatives and instead they called for envisioning alternatives to development (Ziai, 2007). To this end, they focused on grassroots movements, discourses and practices, such as Indigenous and Afro-American movements in countries like Ecuador (Escobar, 2015; Esteva and Prakash, 1998; Ziai, 2007).

It is precisely in this Andean country (as well as in Bolivia) that at the beginning of the $21^{\text {st }}$ century, a new post-development discourse emerged: the so-called "Buen Vivir" (Good Living). Works studying the genealogy of this discourse set its beginning in the year 2000. In the case of Ecuador, that beginning was really just before the constitutional assembly held throughout 2007-2008 when the concept of "Buen Vivir" had a wide acceptance (Altmann, 2013; Breton et al., 2014). As a result of this constitutional process in which different social actors contributed to broaden this discourse's meaning, "Buen Vivir" was recognized in the 2008 Ecuadorian constitution. Since then, this term has become a contentious one. Following Hidalgo-Capitán and Cubillo-Guevara (2014) three main discursive coalitions can be identified: the "indigenistpachamamist" coalition, the "ecologist-post-developmentalist" coalition, and the "socialiststatist" coalition. Each one of these has a different conception of its meaning, but all of them agree on the idea that "Buen Vivir" aims to depart from modern western ideologies, mainly those of nature-society dualism and Eurocentric universalism (Vanhulst and Beiling, 2014; Villaba, 2013; Cortez, 2011). However, it is important to highlight that the visions of the first two coalitions are more ecocentric than that of the Ecuadorian government. Aditionally, many academics have pointed out the significant gap between the Ecuadorian government discourse and its implementation (Villaba-Eguiluz \& Etxano, 2017; Gudynas, 2017; Latorre et al. 2015; Arsel, 2012; Jenkins, 2012; Kröger \& Lalander, 2016; Purcell et al. 2016).

Since its institutionalization in 2008, "Buen Vivir" discourse has received much attention by both scholars and civil society (see Acosta, 2010, 2011, 2013; Altmann, 2013; Breton, Cortéz, \& García S., 2014; Cortez, 2011, 2014; Gudynas, 2009, 2011, 2016; Gudynas \& Acosta, 2011; Hidalgo-Capián \& Cubillo-Guevara, 2014; Hidalgo, 2011; Macas, 2010; Monni \& Pallottino, 2015; Radcliffe, 2012; Ramírez, 2010; Vanhulst, 2015; Vanhulst \& Beling, 2014; 
This is an Accepted Manuscript of the article Latorre, S., \& Malo-Larrea, A. (2019). Policy-making Related Actors' Understandings About Nature-society Relationship: Beyond Modern Ontologies? The Case of Cuenca, Ecuador. Ecological Economics, 156, 387-396., available online

at:https://doi.org/10.1016/j.ecolecon.2018.10.017

(C2018. This manuscript version is made available under the CC-BY-NC-ND 4.0 license.

Villalba, 2013; Viola, 2011; Walsh, 2010). Much of this literature revolves around the following points: a) the genealogy of the concept; b) to what extent this discourse distances itself from traditional visions of development; c) the "other" way of life that this discourse prescribes in opposition to the hegemonic modern way; d) the similarities and differences between this discourse and that of sustainable development; d) different and competing meanings of it among scholars, central government and/or grassroots movements; f) challenges to the definition and implementation of Buen Vivir-based government policies.

However, there are no studies examining the predominant ideas about the nature-society relationship that exist in the Ecuadorian domains of planning and policy making at the subnational level. This is important because the different ways in which nature is interpreted by social actors involved in its management, may inform environmental policy making. Some of these actors include government officials, policy makers and local civil society. Therefore, a better understating of these social perspectives offers insights into potential public attitudes and policy making practices toward more radical sustainable futures.

This article aims to close this aforementioned gap by focusing on the social perspectives about the sustainability of subnational policy makers and other social actors involved in territorial planning. It pays special attention to the ontological conceptions of the world that these sustainability discourses adopt. A case study strategy based on the city of Cuenca is used, as Cuenca is one of the leading cities in environmental policy making and environmental awareness among its citizens. An urbanized and multi-cultural and ethnic based territory is chosen for it is considered to be important to examine social discourses on the nature-society relationship beyond typically rural and indigenous areas. Cities are the predominant socioterritorial configuration in Ecuador, therefore sustainability challenges associated within them have prominence.

Four main social discourses are identified which instead of breaking away from the societynature divide, actually embrace it. Therefore, in the case of Cuenca, this study suggests that Ecuadorian citizens (including policy-makers) are still captured by the same discourses on nature-society that belong to the discursive field of modernity and its more contemporary 
This is an Accepted Manuscript of the article Latorre, S., \& Malo-Larrea, A. (2019). Policy-making Related Actors' Understandings About Nature-society Relationship: Beyond Modern Ontologies? The Case of Cuenca, Ecuador. Ecological Economics, 156, 387-396., available online

at:https://doi.org/10.1016/j.ecolecon.2018.10.017

(C2018. This manuscript version is made available under the CC-BY-NC-ND 4.0 license.

corollaries: development and sustainable development. Hence, relational ontologies promoted by the discourse of "Buen Vivir" still do not resonate amongst policy-related actors.

The article follows with an explanation of our theoretical approach. Afterwards, the methodological strategy adopted to analyze society-nature discourses is presented and then, the main results are developed along with a discussion regarding their interpretation in light of the Buen Vivir discourse's ontological view. A summary of the findings concludes the article.

\section{Discourse theory in sustainability-based science and policy making.}

Until the emergence of post structuralism, the very idea of the constructive character of nature was not imaginable. The society-nature divide has been so fundamental for the development of science and modernity in general that even now realism is the predominant paradigm for many of the scientific disciplines. However, with the post structural turn in the social sciences, an explosion of academic research seeking to denaturalize nature came to be (Escobar, 1996; Bird, 1987; Cronon, 1995; Castree and MacMillan, 2001; Curry, 2003; O'Riordan, 1989; Dingler, 2005). In the words of Castree and Braun (2001), questions such as what society "does" to nature (and vice versa) were replaced by more fundamental ones such as "who constructs what kinds of nature(s) to what ends and with what social and ecological effects" (p.xii).

Post structuralism refers to "a range of theoretical perspectives that can be seen to move away from the tenets of structuralism... Post structuralist research practices put emphasis on identifying meanings that are context specific and that relate to the varying discursive practices operating" (Given, 2008 p.666). Hence, discourse analysis has a central role within this field as it mainly helps highlight both the role of language in constituting policies, polities and politics, and the contingent and contestable character of discourses. The latter, as discourse analysis points out, enables people to see and articulate certain features of the world but not others. 
This is an Accepted Manuscript of the article Latorre, S., \& Malo-Larrea, A. (2019). Policy-making Related Actors' Understandings About Nature-society Relationship: Beyond Modern Ontologies? The Case of Cuenca, Ecuador. Ecological Economics, 156, 387-396., available online

at:https://doi.org/10.1016/j.ecolecon.2018.10.017

(C2018. This manuscript version is made available under the CC-BY-NC-ND 4.0 license.

There are many different conceptions of discourse and discourse analysis, depending on epistemological and ontological understandings of reality, which in turn, have implications for the employed discourse methodology. In general trends, discourse conceptions can be divided between Foucaultian and non-Foucaultian ones (Feindt \& Oels, 2005; Van den Brink \& Metze, 2006). Whereas non-Foucaultian approaches are theoretically related to symbolic interactionism and mainly focus on the linguistic and pragmatic production of meaning, Foucaultian approaches emphasize on the interplay between power and discourse.

According to Feindt and Oels (2005) four characteristics distinguish Foucaultian discourse analysis: a) its focus on the productive function of discourses, i.e., a discourse is constitutive of "reality" in that it physically shapes reality. In this respect, discourse enables and limits the range of practices and interactions in which actors can engage; $b$ ) the assumption that power relations are present in all forms of social interaction, including discourse production and legitimation. There is a politics of meaning, through which, certain discourses get fixed as "truth", while at the same time, marginalizing alternative discourse positions; c) it sees discourse as a "strategic situation" that is formative of actors. Discourses have the capacity of "governing the self"; they play a key role in the construction of subjectivity. However, individuals are never fully determined by a strategic situation, which means that individuals can resist the disciplining effect of hegemonic discourses; d) government strategies to discipline the "self" not only act at the individual level (anatomo-politics), but also at the level of the population as a whole (biopower).

A Foucaultian discourse analysis of nature interprets the category of "nature" as a social construction that is constituted within discourses. In this respect, discourses constitute certain ways of thinking about, representing and acting upon the world. Citing Dryzek (2013), we understand discourse as

"a shared way of apprehending the world, embedded in language; it enables those who subscribe to it to interpret bits of information and put them into coherent stories or accounts.... Each discourse rests on assumptions, judgments, and contentions that provide the basic terms for analysis, debates, agreement, disagreement" (p.9-10) 
This is an Accepted Manuscript of the article Latorre, S., \& Malo-Larrea, A. (2019). Policy-making Related Actors' Understandings About Nature-society Relationship: Beyond Modern Ontologies? The Case of Cuenca, Ecuador. Ecological Economics, 156, 387-396., available online

at:https://doi.org/10.1016/j.ecolecon.2018.10.017

(C2018. This manuscript version is made available under the CC-BY-NC-ND 4.0 license.

As Stevenson (2015) states, this definition directs the analyst's attention to the shared social understandings of a specific issue that can coordinate action, which, is also in line with discourse analysis method of "Q" (please observe the methodology section below).

Foucaultian discourse analysis also reminds us that each discursive conceptualization of nature is fixed through power play, i.e., through discursive clashes what the category of nature might mean in a specific discourse, is discursively fixed. As Dingler (2005) states: "the hegemony of one specific account of nature is not legitimized through a verified correspondence to extra-discursive reality but through relations of power" (p.218). Therefore, "nature" can be conceptualized as a discourse construction and a product of power relations that is constantly invented and reinvented (a politics of nature).

The importance of discourse analysis is increasingly recognized in studies of environmental policy, environmental ethics, political ecology, and related fields. It allows for an understanding of how "nature" is continuously "produced" through environmental policy making, planning, and research as well as through everyday practices. It also highlights how the terms in which particular issues are discussed, and how they define the way in which the topic is experienced thereby noting also the perceived possibilities of action (Feindt and Oels, 2005). Environmental policy literature points out how the modern discourse of natural resources is the hegemonic discourse in planning and policy-making arenas around the world (Hajer and Versteeg, 2005). It assumes the Cartesian dualism between humans and nature as ontologically given. Nature is seen as a pre-social category that encompasses its characteristics independently of the human realm. This is an essentialist view in the sense that materiality is interpreted as a static essence, a pre-given matter that enters the sphere of the symbolic and is interpreted and conceptualized as natural resources to be exploited (Dingler, 2005). This specific vision of nature, in turn, reproduces a certain kind of environmental policy and planning at the expense of alternative ones. Specifically, it allows planners and policy makers to control, forecast and act upon a stable and predictable nature, thereby following the progress path of economic growth and prosperity. In sum, this hegemonic vision reinforces the anthropocentric value of nature and assumes that human wellbeing is based on resource-intensive economic growth. As argued in this article, this 
This is an Accepted Manuscript of the article Latorre, S., \& Malo-Larrea, A. (2019). Policy-making Related Actors' Understandings About Nature-society Relationship: Beyond Modern Ontologies? The Case of Cuenca, Ecuador. Ecological Economics, 156, 387-396., available online

at:https://doi.org/10.1016/j.ecolecon.2018.10.017

(C2018. This manuscript version is made available under the CC-BY-NC-ND 4.0 license.

has detrimental social and environmental consequences, especially for those countries and areas, such as Ecuador where economic development is strongly dependent on extractive activities.

\section{Case study and Methods}

\subsection{The city of Cuenca}

Cuenca is a medium-sized city located in the southern Andes. It encompasses 331,664 hectares: 6,771 hectares (2\%) are urban, 12,013 hectares (3.6\%) are semi-urban, and 312,880 hectares (94.3\%) are rural (Alcaldía de Cuenca, 2012). Its population stands at 505,000 inhabitants, 331,888 (65.6\%) of whom are urban and 173,697 (34.6\%) of whom are rural (INEC, 2010a). In terms of racial-ethnic identification, $89.7 \%$ are Mestizos, $1.8 \%$ are Indigenous, 2.2\% are Afro-Ecuadorians, 5.7\% are whites, and $0.4 \%$ Montubios (INEC, 2010a). Cuenca is one of the areas where the process of emigration has played a significant role. This massive emigration dates back to the 1990s, and in recent years the remittances that emigrants send back to their relatives have had a substantial impact particularly in improving the wellbeing of rural inhabitants. Furthermore, the fact that mostly men tend to emigrate, means that there has been a feminization of the rural areas. The active economic population (AEP) accounts for $44.4 \%$, while there is $52.1 \%$ that are underemployed. Out of the total AEP, $11.5 \%$ work in the primary sector, $28.3 \%$ in the secondary sector, and $51.4 \%$ in the tertiary sector (INEC, 2010b).

Cuenca is one of the leading cities in the formulation of environmental policies, which in part, responds to the strong environmental consciousness of its inhabitants. For example, in order to guarantee its water production, it was the first city in Ecuador to protect the native ecosystems (this city is surrounded by moorland and forests) which work as water sources (Artiga, 2008; Barnett, 1988).

At present, Cuenca manages several municipal protected areas and a national park named "Cajas" (Artiga, 2008). In addition, it has implemented an integrated watershed management system through the cooperation of the Municipal Water Corporation (ETAPA) and the National Electricity Corporation (Lloret, 2002). Another important example that shows Cuenca's environmental leadership is also how it was the first city in Ecuador to establish an 
This is an Accepted Manuscript of the article Latorre, S., \& Malo-Larrea, A. (2019). Policy-making Related Actors' Understandings About Nature-society Relationship: Beyond Modern Ontologies? The Case of Cuenca, Ecuador. Ecological Economics, 156, 387-396., available online

at:https://doi.org/10.1016/j.ecolecon.2018.10.017

(C2018. This manuscript version is made available under the CC-BY-NC-ND 4.0 license.

integral waste water treatment system (Artiga, 2008; Lloret, 2002). Moreover, recent developments related to large-scale open cast metal mining activities in the outskirts of the city have reactivated public discussions about "sustainability" and "environmentalism", the relationship of subordination of rural communities to urban centers, and about unequal power relationships between citizens. Specifically, grassroots social groups living near these extractive areas are claiming that while urban areas receive most of the goods that mining activities entail, they (rural/poor/indigenous/women) bear most of socio-ecological costs of it (Latorre et al., 2015).

\subsection{The Q Methodology}

The Q methodology was designed by William Stephenson at the beginning of the 1930s to statistically study subjectivity in its different forms and in a structured manner (Barry and Proops, 1999; Brown, 1980, 1998). Q operates under the assumption of finite diversity, as there are generally a limited number of ordered patterns of viewpoints for any topic. Therefore, Q extracts latent forms of discourse or social perspectives understood as socially shared patterns of meaning. The importance of this method is based on its ability to quantitatively analyze qualitative information.

A Q study generally comprises five steps: (1) design the Q-set; (2) select participants; (3) administer the Q sort; (4) conduct a factor analysis using specialized Q software; and (5) interpret the qualitative meaning of the factor structure (Barry \& Proops, 1999; Brown, 1993, 1998; Osses, 2009; Stevenson, 2015; Zografos, 2007). We proceed to explain each step for our case study:

$Q$-set design: The $\mathrm{Q}$ set is a set of statements presented to participants that are sorted into a matrix to reflect their view on a given issue. These statements should contain expressions of all the perspectives on this issue. It is normally designed from interviews and/or published materials. In this study both sources were used: (1) published academic, official and press materials about nature-society, territorial planning and land management in Cuenca from 
This is an Accepted Manuscript of the article Latorre, S., \& Malo-Larrea, A. (2019). Policy-making Related Actors' Understandings About Nature-society Relationship: Beyond Modern Ontologies? The Case of Cuenca, Ecuador. Ecological Economics, 156, 387-396., available online

at:https://doi.org/10.1016/j.ecolecon.2018.10.017

(C2018. This manuscript version is made available under the CC-BY-NC-ND 4.0 license.

2009 to $2011^{1}$; and (2) Seven interviews of governmental, private and academic key actors related to rural communities, territorial planning and conservation were conducted in 2016. An initial set of 174 statements (the concourse) were obtained. The most important aspect of compiling statements is to ensure that they reflect the tone and substance of public communication, rather than the voice of the researcher. This means that the bias was reduced by selecting Q statements verbatim from all the perspectives on this topic, but the selection of statements is still an irreducible methodological value judgment. Furthermore, strategic sampling sometimes is used to ensure that the $\mathrm{Q}$ statements represent the entire concourse. This means that the concourse is divided into categories, and potential Q statements are sorted into these categories. These categories can be either theoretically or inductively created. In our case, a theoretical approach that used two categories ("Human-Nature relationship" and "Urban-Rural relationship") was adopted as the main interest was to explore dualist/nondualist ontological understandings of reality. In this respect, these two categories are the main dualist-based relationships that also tend to have a subordinated connection. The final set of Q statements ( $\mathrm{Q}$ sample) is selected by choosing a small number of statements from each category. Our Q sample was comprised of 95 statements identified through content analysis using the software Nvivo.

Participants' selection: Q uses a non-random sampling technique to select the participants. This means that the selection process was followed attending to comprehensiveness and diversity rather than representativeness or quantity. In this regard, the participants were selected based on a stakeholder map of territorial planning and land management created by the municipality of Cuenca. This map included academic, public, productive and various private stakeholders. This was complemented by taking into consideration policy competences around nature conservation and territorial planning. A total of 32 social actors agreed to participate in this study.

\footnotetext{
${ }^{1}$ In 2009, we began to cover two different periods of municipal policies (2009-2013; 2014-2018). We stopped at 2011 as we arrived at a theoretical saturation point in which more data was not leading to more relevant information to represent the total of communication on this issue. However, the interviews conducted in 2016 aimed to make sure that all the perspectives on the topic were considered as in 2014 the newly elected Cuenca mayor was from a different political party from the previous one.
} 
This is an Accepted Manuscript of the article Latorre, S., \& Malo-Larrea, A. (2019). Policy-making Related Actors' Understandings About Nature-society Relationship: Beyond Modern Ontologies? The Case of Cuenca, Ecuador. Ecological Economics, 156, 387-396., available online

at:https://doi.org/10.1016/j.ecolecon.2018.10.017

(C2018. This manuscript version is made available under the CC-BY-NC-ND 4.0 license.

Administering the $Q$ sort: The Q sample of 95 statements was applied to the 32 social actors in order to obtain the Q sorts. This proportion (32:95) meets the recommended ratio proportion of statements/participants which is 1:3 (Osses, 2009).

The set was organized in a quasi-normal distribution and Likert-type matrix: using a value scale of 11 levels: from -5 (completely disagree) to +5 (agree completely), including 0 (indifferent). The person conducting the $\mathrm{Q}$ assessment was asked to read and organize cards with the statements in three groups: one for statements with which he/she agreed, another for statements about which he/she felt indifferent and another for statements with which he/she disagreed. Subsequently, each statement was reviewed again and assessed using the Likert matrix. Five Q sorts were discarded because of incoherencies in the sorting process. So finally, with 27 Q sorts were used (see Table No. 1).

\section{Table 1: the 27 participants ( $Q$ sorts)}

Mayor of Cuenca

Deputy Mayor of Cuenca

President of Cuenca's Consortium of Rural Parishes

City Counselor

Presidents of all the Rural Parishes (13 of 21)

Planning Regional Director of Planning and Development Ministry

(SENPLADES-Austro)

Provincial Director of Environmental Ministry

Manager of Cuenca's Telephone, Potable Water and Sewer System Company

Environmental Technician of Cuenca's Telephone, Potable Water and Sewer System Company

Manager of Cajas National Park

Rector of University of Cuenca

Rector of University of Azuay

Dean of Azuay University’s Science and Technology faculty

Director of Azuay University's Biology, Ecology and Management department

\section{Type of social actor}

Urban Public

Urban Public

Rural Public

Urban Public

Rural Public

Urban Public

Urban Public

Urban Public

Urban Public

Urban Public

Urban Academic

Urban Academic

Urban Academic

Urban Academic 
This is an Accepted Manuscript of the article Latorre, S., \& Malo-Larrea, A. (2019). Policy-making Related Actors' Understandings About Nature-society Relationship: Beyond Modern Ontologies? The Case of Cuenca, Ecuador. Ecological Economics, 156, 387-396., available online

at:https://doi.org/10.1016/j.ecolecon.2018.10.017

(อ2018. This manuscript version is made available under the CC-BY-NC-ND 4.0 license.

President of Cuenca's Chamber of Commerce

Urban Private

Private Environmental Consultant

Urban Private

Factor Analysis: The PQ Method Software was used while applying a centroid factor analysis and a manual rotation. Factor extraction is a statistical process resulting from the correlation of all the $\mathrm{Q}$ sorts with one another. Centroid algorithm is based on the commonality among Q sorts and ignores the specificity of individuals' sorts. Therefore, factors represent clusters of correlated sorts with a common position (social perspectives) on a specific topic that account for as much variance as possible. The software generates a factor loading table indicating the defining sorts, i.e., the sorts (participants) that are highly associated with each factor. In this case, following standard procedures, statistical significance of loading cases in each factor was determined at $0.26^{2}$. Furthermore, a total of 40 respondents loaded onto one or more of the four factors.

Table 2, shows that there are several cofounders, i.e., respondents who are highly correlated with more than one factors. Specifically, these cofounders generally load to factor 3 and other factors. This is explained due to the widespread view represented by factor 3 among participants which also has the highest explained variance. This issue was addressed in the results and discussion section. Finally, four factors were obtained which accounted for $57 \%$ of variance.

\footnotetext{
${ }^{2}$ In order to calculate its statistical significance we applied the formula: $(\mathrm{SSV})=2.58 * \mathrm{SE} ; S E=\frac{1}{\sqrt{n}} ; \mathrm{n}=$ statement number (Osses, 2009; Zografos, 2007).
} 
This is an Accepted Manuscript of the article Latorre, S., \& Malo-Larrea, A. (2019). Policy-making Related Actors' Understandings About Nature-society Relationship: Beyond Modern Ontologies? The Case of Cuenca, Ecuador. Ecological Economics, 156, 387-396., available online

at:https://doi.org/10.1016/j.ecolecon.2018.10.017

(อ2018. This manuscript version is made available under the CC-BY-NC-ND 4.0 license.

\begin{tabular}{|c|c|c|c|c|c|}
\hline \multicolumn{6}{|c|}{ Table 2: Q sorts' factor loadings } \\
\hline \multicolumn{2}{|c|}{ Q SORT } & FACTOR 1 & FACTOR 2 & FACTOR 3 & FACTOR 4 \\
\hline 1 & Rural1 & $-0,2089$ & 0,0522 & $-0,1220$ & $0,3679 X$ \\
\hline 2 & Rural2 & $0,2611 X$ & 0,1274 & $-0,2518$ & 0,1575 \\
\hline 3 & Rural3 & 0,0336 & $0,3177 X$ & $-0,2559$ & 0,1412 \\
\hline 4 & Rural4 & $-0,1038$ & 0,1874 & $-0,2702 X$ & 0,1531 \\
\hline 5 & Rural5 & $-0,5167 X$ & 0,1053 & $-0,1249$ & 0,1652 \\
\hline 6 & Rural8 & 0,0786 & 0,1454 & $-0,1638 X$ & $0,2729 X$ \\
\hline 7 & Rural10 & $-0,4989 X$ & $-0,0295$ & $-0,5517 X$ & 0,1065 \\
\hline 8 & Rural11 & 0,1931 & 0,0417 & $-0,3972 X$ & $-0,0529$ \\
\hline 9 & Rural12 & $-0,1745$ & 0,0658 & $-0,5869 X$ & 0,0440 \\
\hline 10 & Rural13 & $-0,1640$ & $0,4588 X$ & $-0,1278$ & $-0,1555$ \\
\hline 11 & Rural16 & $-0,0430$ & $0,6281 X$ & $-0,0724$ & $-0,3088 \mathrm{X}$ \\
\hline 12 & Rural17 & $-0,1895$ & $0,5896 X$ & $-0,0947$ & $-0,3517 X$ \\
\hline 13 & Rural18 & $-0,1973$ & $0,3928 X$ & $-0,2864 X$ & 0,1829 \\
\hline 14 & Rural19 & $-0,0623$ & $-0,1140$ & $-0,4445 X$ & $-0,1621$ \\
\hline 15 & Urban1 & 0,0956 & $0,2841 X$ & $-0,5190 X$ & 0,2539 \\
\hline 16 & Urban2 & 0,0430 & $0,4022 \mathrm{X}$ & $-0,3152 X$ & $-0,0433$ \\
\hline 17 & Urban4 & $0,3956 \mathrm{X}$ & 0,0893 & $-0,5682 X$ & 0,2488 \\
\hline 18 & Urban5 & 0,2007 & $-0,0973$ & $-0,6339 X$ & 0,0136 \\
\hline 19 & Urban6 & $0,5613 \mathrm{X}$ & 0,0158 & $-0,3854 X$ & $-0,0165$ \\
\hline 20 & Urban7 & $0,2797 \mathrm{X}$ & 0,0744 & $-0,6216 \mathrm{X}$ & 0,2171 \\
\hline 21 & Urban8 & $0,2656 X$ & 0,2115 & $-0,4945 X$ & 0,1682 \\
\hline 22 & Urban9 & 0,0833 & $0,3244 X$ & $-0,3363 X$ & 0,1386 \\
\hline 23 & Urban 10 & $-0,1448$ & $-0,1470$ & $-0,5239 X$ & $-0,0091$ \\
\hline 24 & Urban 11 & $-0,0644$ & 0,0309 & $-0,5691 X$ & $-0,1340$ \\
\hline 25 & Urban 12 & 0,1115 & 0,1237 & $-0,4268 X$ & $0,5357 X$ \\
\hline 26 & Urban13 & 0,0064 & 0,1482 & $-0,6141 X$ & $0,2972 X$ \\
\hline 27 & Urban 14 & $-0,0205$ & 0,1232 & $-0,7205 X$ & 0,0994 \\
\hline \multicolumn{2}{|c|}{ Explained variance } & $12 \%$ & $14 \%$ & $21 \%$ & $10 \%$ \\
\hline
\end{tabular}

Narrative account: Finally, an interpretation of the factors or discourses is undertaken based on the distinguishing statements (statistically significant statements) for each factor (see tables 3; 4, 5, 6 for factors 1-4 respectively). ${ }^{3}$ This is complemented by qualitative data from the $\mathrm{Q}$ interviews. In line with $\mathrm{Q}$ methodology convention, the discourses have been assigned titles, to aid communication and understanding of the results. We proceed to interpret and explain each discourse.

\section{Results and discussion}

\footnotetext{
${ }^{3}$ Z-scores indicate the relationship between statements and factors, i.e., how much each factor agrees with a statement. They are a weighted average of the scores given by the flagged Q sorts to that statement.
} 
This is an Accepted Manuscript of the article Latorre, S., \& Malo-Larrea, A. (2019). Policy-making Related Actors' Understandings About Nature-society Relationship: Beyond Modern Ontologies? The Case of Cuenca, Ecuador. Ecological Economics, 156, 387-396., available online

at:https://doi.org/10.1016/j.ecolecon.2018.10.017

(02018. This manuscript version is made available under the CC-BY-NC-ND 4.0 license.

The four discourses obtained were named respectively as "Pessimist", "Nostalgic", "Techno-modernist", and "Optimist". It is important to note that all of them are formed by urban-rural coalitions. This means that none of them was composed exclusively of urban or rural stakeholders. This is a very interesting result because it shows that the different understandings of nature-society are not correlated with the (urban-rural) space position of the stakeholders.

\subsection{Four Environmental Discourses}

\subsubsection{Pessimist Discourse}

The distinguishing statements of this discourse are: agreement $(53,75,66,8,34,12,22,35$, $74,5,70,30,11,52,54$, and 29) and disagreement (13, 77, 81, 95, 87, 19, 86, 92, and 91).

Table 3: Distinguishing statements for Factor 1: Pessimist

\begin{tabular}{|c|l|c|}
\hline $\begin{array}{c}\text { Statement } \\
\text { Number }\end{array}$ & \multicolumn{1}{|c|}{ Statements } & $\begin{array}{c}\text { Z- } \\
\text { score }\end{array}$ \\
\hline 53 & Technology cannot fix the environmental problems we face as human beings & $\mathbf{2 , 3 2}$ \\
\hline 75 & $\begin{array}{l}\text { Urban citizens demand ecosystems services of quality but they are not willing to } \\
\text { assume the costs of conservation that this entails }\end{array}$ & $\mathbf{2 , 1 7}$ \\
\hline 66 & $\begin{array}{l}\text { The "urban" is where the people live and work and is characterized by human made } \\
\text { artifacts }\end{array}$ & $\mathbf{1 , 8 2}$ \\
\hline 8 & $\begin{array}{l}\text { The future is worrisome because coming development projects such as mining } \\
\text { concessions will have detrimental consequences for the health and wellbeing of the } \\
\text { inhabitants but also for the environment }\end{array}$ & $\mathbf{1 , 7 8}$ \\
\hline 34 & Resource-intensive economic growth is the cause of our environmental problems & $\mathbf{1 , 6 3}$ \\
\hline 12 & Human beings are a threat to the environment & $\mathbf{1 , 6 3}$ \\
\hline 22 & In urban areas natural elements are very rare & $\mathbf{1 , 6 2}$ \\
\hline 35 & The urban lifestyle undervalues rural values and lifestyle & $\mathbf{1 , 6 2}$ \\
\hline 74 & In urban areas human beings cannot coexist with other non-human species & $\mathbf{1 , 5 6}$ \\
\hline 5 & Nature will only be preserved if rural people do not desire to live as urban people & $\mathbf{1 , 3 1}$ \\
\hline 70 & $\begin{array}{l}\text { Whereas science and technology only take place in urban areas, traditional } \\
\text { knowledge is generated only in rural areas }\end{array}$ & $\mathbf{0 , 9 2}$ \\
\hline 30 & Nature is mainly understood as natural resources to be used by humans & $\mathbf{0 , 5 2}$ \\
\hline 11 & There are two different systems: the socio-cultural and the biophysical & $\mathbf{0 , 2 8}$ \\
\hline 52 & Urban people only value nature for its amenities & $\mathbf{0 , 2 3}$ \\
\hline 54 & As nature is found in rural areas, it is the duty of rural people to preserve it & $\mathbf{0 , 0 9}$ \\
\hline 29 & Rural areas are characterized by underdevelopment and backwardness & $\mathbf{0 , 0 8}$ \\
\hline 13 & Human beings do no longer need nature for their wellbeing & $\mathbf{- 0 , 3 6}$ \\
\hline 77 & $\begin{array}{l}\text { The state through territorial planning can solve most of the environmental problems } \\
\text { that Cuenca faces }\end{array}$ & $\mathbf{- 0 , 7 3}$ \\
\hline 81 & Rural people have the same material wellbeing as urban people have & $\mathbf{- 1 , 0 2}$ \\
\hline
\end{tabular}


This is an Accepted Manuscript of the article Latorre, S., \& Malo-Larrea, A. (2019). Policy-making Related Actors' Understandings About Nature-society Relationship: Beyond Modern Ontologies? The Case of Cuenca, Ecuador. Ecological Economics, 156, 387-396., available online

at:https://doi.org/10.1016/j.ecolecon.2018.10.017

(02018. This manuscript version is made available under the CC-BY-NC-ND 4.0 license.

\begin{tabular}{|c|l|c|}
95 & $\begin{array}{l}\text { I would like to return to the past when people lived in a healthy way: eating in an } \\
\text { organic and local way }\end{array}$ & $\mathbf{- 1 , 2 3}$ \\
\hline 87 & $\begin{array}{l}\text { Going back to the past, when humans based their livelihood on agriculture is the } \\
\text { solution for the current environmental crisis }\end{array}$ & $\mathbf{- 1 , 5 4}$ \\
\hline 19 & In rural areas people live with more freedom & $\mathbf{- 1 , 6 7}$ \\
\hline 86 & In the past human beings lived in harmony with nature & $\mathbf{- 1 , 8 1}$ \\
\hline 92 & Nature has intrinsic value & $\mathbf{- 2 , 2 2}$ \\
\hline 91 & Human beings can control and forecast nature & $\mathbf{- 2 , 5 8}$ \\
\hline
\end{tabular}

Significance level of $\mathrm{p}<0.01$

\section{Human-Nature relationship}

The pessimist discourse has a negative view of the future as it conceives the society-nature dichotomy as a relationship between an aggressor (society) and a victim (nature). This is well expressed by both the statements 12: "Human beings are a threat to the environment" and 8: "The future is worrisome because coming development projects such as mining concessions will have detrimental consequences for the health and wellbeing of the inhabitants but also for the environment". This discourse emphasizes the resource-intensive economic growth of the Ecuadorian economy as the main cause of environmental problems. This pessimistic view is exacerbated by a lack of belief and trust in the binomial of science and technology to solve the environmental crisis in which it believes that we live (53 and 91) as well as the adoption of a managerial approach (77). It operates under the assumption that reality is comprised by two different spheres: the socio-cultural and biophysical (11). In this respect, it assumes that humanity depends on nature for its wellbeing and also that it values nature mainly in instrumental terms, i.e. because of its material-economic value (13, and 92). In this sense, this discourse sees the interrelation between the social and the bio-physical systems, but also reinforces the nature-society dichotomy. It is interesting that it has a negative vision of the past in the sense that recovering certain characteristics of the past, such as agrarian and rural lifestyles, is not worthwhile (95 and 87).

\section{Urban-Rural relationship}

This discourse has a vision of the urban domain as defined based on population density, human-made artifacts and in opposition to wild nature $(75,66,22$, and 54$)$. It is a space 
This is an Accepted Manuscript of the article Latorre, S., \& Malo-Larrea, A. (2019). Policy-making Related Actors' Understandings About Nature-society Relationship: Beyond Modern Ontologies? The Case of Cuenca, Ecuador. Ecological Economics, 156, 387-396., available online

at:https://doi.org/10.1016/j.ecolecon.2018.10.017

(02018. This manuscript version is made available under the CC-BY-NC-ND 4.0 license.

dominated by technological artifacts in contrast with the rural sphere where tradition and ancestral practices predominate (70). In this sense, visions of nature as domesticated and productive are nature paradigms not considered within this discourse. On the contrary, the wild vision of nature is the predominant one.

What is "rural" is principally associated with agricultural land use and backwardness that, according to this concept, give the rural sphere a more "natural" character in comparison to the urban sphere (54). In the relationship between the urban and the rural spheres, it states that there has been a long-standing process of marginalization and subordination of the rural sphere by the urban, as these two statements indicate: "The urban lifestyle undervalues rural values and lifestyle" and the disagreement with: "Rural people have the same material wellbeing than urban people have". This explains why rural areas are perceived as characterized by backwardness and underdevelopment (29).

\subsubsection{Nostalgic Discourse}

The distinguishing statements of this discourse are: agreement $(40,62,87,95,88,39,24$, $74,26,32,48,90,35,36,37,67,80$ and 61$)$ and disagreement $(92,28,54,34,84,14,29$ and 13).

Table 4: Distinguishing statements for Factor 2: Nostalgic

\begin{tabular}{|c|l|c|}
\hline $\begin{array}{c}\text { Statement } \\
\text { Number }\end{array}$ & Statements & $\begin{array}{c}\text { Z- } \\
\text { score }\end{array}$ \\
\hline 40 & Rural people should have the same material conditions as urban people have & 1,53 \\
\hline 62 & Rural areas give many inputs to urban areas but the opposite is not the case & 1,49 \\
\hline 87 & $\begin{array}{l}\text { Going back to the past when humans based their livelihood on agriculture is the } \\
\text { solution for the current environmental crisis }\end{array}$ & 1,36 \\
\hline 95 & $\begin{array}{l}\text { I would like to return to the past when people lived in a healthy way: eating in } \\
\text { an organic and local way }\end{array}$ & 1,26 \\
\hline 88 & $\begin{array}{l}\text { Participatory planning processes are necessary to avoid rural subordination to } \\
\text { urban areas }\end{array}$ & 1,25 \\
\hline 39 & $\begin{array}{l}\text { Urban technological progress is the main cause of the environmental problems } \\
\text { we face nowadays }\end{array}$ & 1,16 \\
\hline 24 & I hope my children live in an environment as healthy as the one I lived in & 1,14 \\
\hline 74 & In urban areas human beings cannot coexist with other non-human species & 1,12 \\
\hline 26 & $\begin{array}{l}\text { I wish to live in more rural-like cities with more green areas and with more } \\
\text { presence of natural elements }\end{array}$ & 1,07 \\
\hline 32 & Biodiversity is a strategic resource for meeting humans' needs and survival & 1,01 \\
\hline
\end{tabular}


This is an Accepted Manuscript of the article Latorre, S., \& Malo-Larrea, A. (2019). Policy-making Related Actors' Understandings About Nature-society Relationship: Beyond Modern Ontologies? The Case of Cuenca, Ecuador. Ecological Economics, 156, 387-396., available online

at:https://doi.org/10.1016/j.ecolecon.2018.10.017

(C2018. This manuscript version is made available under the CC-BY-NC-ND 4.0 license.

\begin{tabular}{|c|l|c|}
\hline 48 & $\begin{array}{l}\text { Urban people lack environmental consciousness due to their isolation from } \\
\text { nature }\end{array}$ & 0,94 \\
\hline 90 & We should create more protected areas to avoid nature destruction & 0,72 \\
\hline 35 & The urban lifestyle undervalues rural values and lifestyle & 0,68 \\
\hline 36 & $\begin{array}{l}\text { Humans beings do not need to build reciprocal relationships with non-human } \\
\text { beings, such as animals, plants, mountains, etc. }\end{array}$ & 0,59 \\
\hline 37 & $\begin{array}{l}\text { The historical marginalization of rural people in terms of access to land and } \\
\text { productive factors is causing some environmental problems nowadays }\end{array}$ & 0,58 \\
\hline 67 & Urban areas are mainly defined by their high population density & 0,56 \\
\hline 80 & $\begin{array}{l}\text { Rural people might have traditional knowledge which could be useful for a } \\
\text { sustainable management of the natural resources }\end{array}$ & 0,41 \\
\hline 61 & $\begin{array}{l}\text { There is an interdependence between rural and urban areas in terms of goods } \\
\text { and services }\end{array}$ & 0,33 \\
\hline 92 & Nature has intrinsic value & $-1,01$ \\
\hline 28 & Mountains, trees, and animals are beings with will and agency & $-1,15$ \\
\hline 54 & As nature is found in rural areas, it is the duty of rural people to preserve it & $-1,01$ \\
\hline 34 & $\begin{array}{l}\text { Resource-intensive economic growth is the cause of our environmental } \\
\text { problems }\end{array}$ & $-1,25$ \\
\hline 84 & Human beings are determined by natural laws & $-1,51$ \\
\hline 14 & Nature should have political rights just as humans do & $-1,87$ \\
\hline 29 & Rural areas are characterized by underdevelopment and backwardness & $-2,10$ \\
\hline 13 & Human beings no longer depend on nature for their wellbeing & $-4,19$ \\
\hline$S 19 n i c a n$ & level of 0.01 & \\
\hline
\end{tabular}

Significance level of $p<0.01$

\section{Human-Nature relationship}

The nostalgic discourse can be considered as having a romantic view of the past, especially of the rural lifestyle. The nostalgia that characterizes this view is based on the belief that everything was better in the past; a past when human beings were living in harmony with nature by living from the land. In that sense, it assumes that in the past people were healthier, ate local and organic food and lived in a sustainable way. This is well illustrated by the following statement: "Going back to the past, when humans based their livelihood on agriculture, is the solution for the current environmental crisis". Thus, according to this discourse, the fundamental problem is that modern society characterized by technology and urban lifestyle represents the opposite of good living and that modern society is the reason for the alleged environmental crisis $(39,74,24$ and 48). This vision of the past means that it does not view humans beings as a threat per se to nature, but instead blames the technological advances and the present urban way of living. Furthermore, it acknowledges the key role that nature plays in human wellbeing (13). Moreover, it adopts a stewardship vision according to which humans should protect nature (90) mainly because of its instrumental role for human 
This is an Accepted Manuscript of the article Latorre, S., \& Malo-Larrea, A. (2019). Policy-making Related Actors' Understandings About Nature-society Relationship: Beyond Modern Ontologies? The Case of Cuenca, Ecuador. Ecological Economics, 156, 387-396., available online

at:https://doi.org/10.1016/j.ecolecon.2018.10.017

(C2018. This manuscript version is made available under the CC-BY-NC-ND 4.0 license.

wellbeing (32, 92 and 14). However, it accepts, as does the former discourse, an ontological dichotomy between society and nature. This is expressed by the opposition to more relational ontologies as expressed by the following statements: "Humans beings do not need to build reciprocal relationships with non-human beings, such as animals, plants, mountains, etc." and the disagreement with: "Mountains, trees, and animals are beings with will and agency".

\section{Urban-Rural relationship}

As mentioned above, the Nostalgic Discourse conceptualizes the urban sphere as the antithesis of pristine nature and of the rural sphere (74, and 35). In this respect, like the Pessimist Discourse, it exclusively adopts a vision of nature as wild. Moreover, it adopts a normative view that states that the rural sphere has been marginalized and exploited by the urban sphere which has entailed socio-environmental problems and should be redressed (40, 62, 35, and 29). Also, it positively values tradition and ruralness. These areas are not defined by underdevelopment and backwardness, but, on the contrary, are the ideal images for cities. The following statement illustrates this point: "I wish to live in more rural-like cities with more green areas and with more presence of natural elements". Moreover, rural inhabitants are seen as holders of traditional knowledge which might be useful for sustainable practices (80). In this line, urban inhabitants are seen as lacking environmental consciousness because of their isolation from nature (48). It is interesting to note that despite the fact that this discourse considers urban lifestyle as the main culprit of environmental problems, it also considers that the marginalization of rural inhabitants in terms of access to productive factors is causing some environmental problems (37). In this respect, this discourse adopts, like the Pessimist Discourse, a stewardship position of humans over nature (90).

\subsubsection{Techno-Modernist Discourse}

This is the most dominant discourse within the participating stakeholders, as it has the highest explained variance with a $21 \%$. The distinguishing statements of this discourse are: agreement $(13,73,77,29,43,91,20,64,46,18,11,27,54$, and 21) and disagreement $(86,6,80,9,65$, $38,78,57,79,94,87,92,50,3,33,1,88,90,53$ and 2). 
This is an Accepted Manuscript of the article Latorre, S., \& Malo-Larrea, A. (2019). Policy-making Related Actors' Understandings About Nature-society Relationship: Beyond Modern Ontologies? The Case of Cuenca, Ecuador. Ecological Economics, 156, 387-396., available online

at:https://doi.org/10.1016/j.ecolecon.2018.10.017

(C2018. This manuscript version is made available under the CC-BY-NC-ND 4.0 license.

Table 5: Distinguishing statements for Factor 3: Techno-modernist

\begin{tabular}{|c|c|c|}
\hline $\begin{array}{l}\text { Statement } \\
\text { Number }\end{array}$ & Statements & $\begin{array}{c}\mathbf{Z} \text { - } \\
\text { score }\end{array}$ \\
\hline 13 & Human beings no longer depend on nature for their wellbeing & 3,64 \\
\hline 73 & There is no relationship between urban and rural areas & 2,82 \\
\hline 77 & $\begin{array}{l}\text { The state, through territorial planning, can solve most of the environmental } \\
\text { problems that Cuenca faces }\end{array}$ & 2,63 \\
\hline 29 & Rural areas are characterized by underdevelopment and backwardness & 1,99 \\
\hline 43 & Urban lifestyle and values mean progress and prosperity & 1,76 \\
\hline 91 & Human beings can control and forecast nature & 1,62 \\
\hline 20 & Rural areas are chaotic because of a lack of proper territorial planning processes & 1,33 \\
\hline 64 & $\begin{array}{l}\text { The future is promising for humans because we have never before had such } \\
\text { wealth and progress }\end{array}$ & 1,29 \\
\hline 46 & $\begin{array}{l}\text { Urban people value nature higher than rural people do because the former have } \\
\text { material prosperity }\end{array}$ & 1,20 \\
\hline 18 & Rural people's backwardness is causing several environmental problems & 1,15 \\
\hline 11 & There are two different systems: the socio-cultural and the biophysical & 1,12 \\
\hline 27 & Most environmental problems have their roots in poverty & 1,01 \\
\hline 54 & As nature is found in rural areas, it is the duty of rural people to preserve it & 0,97 \\
\hline 21 & $\begin{array}{l}\text { Urban areas are sustainable because there exist rules and proper planning } \\
\text { processes }\end{array}$ & 0,66 \\
\hline 86 & In the past, human beings lived in harmony with nature. & $-0,14$ \\
\hline 6 & Natural resource scarcity and resource wars will happen in the future & $-0,17$ \\
\hline 80 & $\begin{array}{l}\text { Rural people might have traditional knowledge which could be useful for a } \\
\text { sustainable management of natural resources }\end{array}$ & $-0,33$ \\
\hline 9 & $\begin{array}{l}\text { Nature is a relational continuum between human beings and non-human beings, } \\
\text { such as animals, plants, mountains, etc. }\end{array}$ & $-0,35$ \\
\hline 65 & $\begin{array}{l}\text { We need to prioritize redistribution of the means of production rather than } \\
\text { economic growth }\end{array}$ & $-0,49$ \\
\hline 38 & $\begin{array}{l}\text { Modern technology such as green revolution technologies have had detrimental } \\
\text { consequences for Ecuadorian rural areas }\end{array}$ & $-0,58$ \\
\hline 78 & Humans beings are only one more specie of the planet & $-0,59$ \\
\hline 57 & Rural areas play a key role as supply zones for cities & $-0,70$ \\
\hline 79 & In urban areas people suffer from spiritual poverty & $-0,98$ \\
\hline 94 & All living beings have the same right to live as human beings have & $-1,11$ \\
\hline 87 & $\begin{array}{l}\text { Going back to the past when humans based their livelihood on agriculture, is the } \\
\text { solution for the current environmental crisis }\end{array}$ & $-1,21$ \\
\hline 92 & Nature has intrinsic value & $-1,22$ \\
\hline 50 & We need to protect nature for the wellbeing of future generations & $-1,29$ \\
\hline 3 & Nature can be a threat to human beings & $-1,30$ \\
\hline 33 & Communal management is the best way to protect nature & $-1,33$ \\
\hline 1 & Human progress should take into consideration its environmental consequences & $-1,41$ \\
\hline 88 & $\begin{array}{l}\text { Participatory planning processes are necessary to avoid rural subordination to } \\
\text { urban areas }\end{array}$ & $-1,43$ \\
\hline 90 & We should create more protected areas to avoid nature destruction & $-1,48$ \\
\hline 53 & Technology cannot fix the environmental problems we face as human beings & $-1,48$ \\
\hline 2 & Nature is a vulnerable system for which we are responsible & $-1,67$ \\
\hline
\end{tabular}

Significance level of $\mathrm{p}<0.01$

\section{Human-Nature relationship}


This is an Accepted Manuscript of the article Latorre, S., \& Malo-Larrea, A. (2019). Policy-making Related Actors' Understandings About Nature-society Relationship: Beyond Modern Ontologies? The Case of Cuenca, Ecuador. Ecological Economics, 156, 387-396., available online

at:https://doi.org/10.1016/j.ecolecon.2018.10.017

(C2018. This manuscript version is made available under the CC-BY-NC-ND 4.0 license.

The techno-modernist discourse has a completely different view of the relationship between humans and nature in comparison with the other three discourses. In contrast to the others, it claims that nature is no longer necessary for humans. It neglects the human dependence on nature for our survival and assumes a dominant position of humans over nature, as the following statements show: strong agreement with: "Human beings no longer depend on nature for their wellbeing" and strong disagreement with: "Nature is a vulnerable system for which we are responsible". Furthermore, it does not consider other living species as having rights equal to those of human beings (78 and 94), and therefore, nature conservation is justified neither for its instrumental nor its intrinsic values (50, 92 and 90). It also has an optimistic view of the future based on technological progress and modernization $(64,6,38,1,53$ and 65). This is illustrated by the following statements: totally agree with "The future is promising for humans because never before have we had such wealth and progress" and disagree with: "Natural resource scarcity and resource wars will happen in the future". This is complemented by a mastery and managerial position of humans over nature reflected in the assumption that humans can control and forecast nature which in turn entails that nature cannot be a threat to humans (77, 91 and 3).

This discourse, like the others, rejects a more relational ontology by stressing the distinction between the social and the biophysical as different domains (11 and 9).

\section{Urban-Rural relationship}

The techno-modernist discourse considers the urban sphere to be autonomous with no connections to rural areas (73, and 57). It also conceives the urban domain as sustainable, where everything is planned, regulated and modern in contrast to what exists in the rural areas (43, and 21). This is illustrated by the following statement: "Urban areas are sustainable because there exist rules and proper planning processes". The rural sphere is conceived as a backward area where development has not as yet arrived; therefore, everything there is unplanned and chaotic (29, and 18). Interestingly, it views rural and poor inhabitants as the principal culprits for the environmental problems that humans face (27). 
This is an Accepted Manuscript of the article Latorre, S., \& Malo-Larrea, A. (2019). Policy-making Related Actors' Understandings About Nature-society Relationship: Beyond Modern Ontologies? The Case of Cuenca, Ecuador. Ecological Economics, 156, 387-396., available online

at:https://doi.org/10.1016/j.ecolecon.2018.10.017

(อ2018. This manuscript version is made available under the CC-BY-NC-ND 4.0 license.

This discourse understands the rural population as ignorant and a predator of nature, as this statement shows "Rural people's backwardness is causing several environmental problems". Moreover, it disregards the potential of traditional knowledge that rural inhabitants might have for sustainable management practices (80). In this respect, it assumes that urban inhabitants have more environmental consciousness than their rural counterparts: "Urban people value nature more highly than do rural people because they have material prosperity". This is in line with post-materialist visions for developing environmental consciousness.

\subsubsection{Optimistic Discourse}

The distinguishing statements of this discourse are: agreement $(10,25,33,48,52,16,17$, $11,4,83,23,75,40,32,92$, and 90) and disagreement $(7,56,9,15,6,13,43,46,12,8,20$ and 54).

Table 6: Distinguishing statements for Factor 4: Optimist

\begin{tabular}{|c|l|c|}
\hline $\begin{array}{c}\text { Statement } \\
\text { Number }\end{array}$ & Statements & $\begin{array}{c}\text { Z- } \\
\text { score }\end{array}$ \\
\hline 10 & $\begin{array}{l}\text { I have faith in humans in the sense that they will finally fix the environmental } \\
\text { challenges that we face nowadays }\end{array}$ & 1,92 \\
\hline 25 & I believe that in the future humans will manage to live in harmony with nature & 1,87 \\
\hline 33 & Communal management is the best way to protect nature & 1,45 \\
\hline 48 & $\begin{array}{l}\text { Urban people lack environmental consciousness due to their isolation from } \\
\text { nature. }\end{array}$ & 1,33 \\
\hline 52 & Urban people only value nature for its amenities & 1,31 \\
\hline 16 & $\begin{array}{l}\text { Rural areas will play a key role in the future to achieve a more balanced } \\
\text { territorial distribution between rural and urban areas. }\end{array}$ & 1,30 \\
\hline 17 & $\begin{array}{l}\text { We need to revalue traditional knowledge and use it to complement scientific } \\
\text { knowledge to advance sustainability. }\end{array}$ & 1,25 \\
\hline 11 & There are two different systems: the socio-cultural and the biophysical & 1,24 \\
\hline 4 & We need to balance economic goals with environmental ones & 0,13 \\
\hline 83 & $\begin{array}{l}\text { Rural people have more environmental consciousness because they rely on } \\
\text { nature directly for meeting their material needs. }\end{array}$ & 0,94 \\
\hline 23 & $\begin{array}{l}\text { Humans can have an attitude of solidarity with other humans and nature if the } \\
\text { institutional context allows it }\end{array}$ & 0,74 \\
\hline 75 & $\begin{array}{l}\text { Urban citizens demand ecosystems services of quality but they are not willing to } \\
\text { assume the costs of conservation that this entails. }\end{array}$ & 0,48 \\
\hline 40 & Rural people should have the same material conditions as urban people have \\
\hline 32 & $\begin{array}{l}\text { Biodiversity is a strategic resource for meeting humans' needs and for assuring } \\
\text { their survival }\end{array}$ & 0,36 \\
\hline
\end{tabular}


This is an Accepted Manuscript of the article Latorre, S., \& Malo-Larrea, A. (2019). Policy-making Related Actors' Understandings About Nature-society Relationship: Beyond Modern Ontologies? The Case of Cuenca, Ecuador. Ecological Economics, 156, 387-396., available online

at:https://doi.org/10.1016/j.ecolecon.2018.10.017

(02018. This manuscript version is made available under the CC-BY-NC-ND 4.0 license.

\begin{tabular}{|c|l|c|}
\hline 92 & Nature has intrinsic value & 0,19 \\
\hline 90 & We should create more protected areas to avoid nature destruction & 0,14 \\
\hline 7 & Rural areas are only valuable as providers of foodstuffs for urban areas & $-0,31$ \\
\hline 56 & We need to promote green technologies more widely to modernize rural areas & $-0,96$ \\
\hline 9 & $\begin{array}{l}\text { Nature is a relational continuum between human beings and non-human beings, } \\
\text { such as animals, plants, mountains, etc. }\end{array}$ & $-1,02$ \\
\hline 15 & Nature must be preserved for its sacredness value & $-1,17$ \\
\hline 6 & Natural resource scarcity and resource wars will happen in the future. & $-1,21$ \\
\hline 13 & Human beings no longer depend on nature for their wellbeing. & $-1,26$ \\
\hline 43 & Urban lifestyle and values mean progress and prosperity & $-1,28$ \\
\hline 46 & $\begin{array}{l}\text { Urban people value nature more highly than do rural people because they have } \\
\text { material prosperity }\end{array}$ & $-1,70$ \\
\hline 12 & Human beings are a threat to the environment. & $-2,23$ \\
\hline 8 & $\begin{array}{l}\text { The future is worrisome because coming development projects such as mining } \\
\text { concessions will have detrimental consequences for the health and wellbeing of } \\
\text { the inhabitants but also for the environment. }\end{array}$ & $-2,31$ \\
\hline 20 & Rural areas are chaotic because of a lack of proper territorial planning processes. & $-2,31$ \\
\hline 54 & As nature is found in rural areas, it is the duty of rural people to preserve it. & $-2,96$ \\
\hline
\end{tabular}

Significance level of $\mathrm{p}<0.01$

\section{Human-Nature relationship}

The optimist discourse does not see human beings as a threat to nature by itself. In fact, one of the statements it rejects the most sustains that: "human beings are a threat to nature". It assumes that a harmonious cohabitation between society and nature is possible as the following statements show: "I have faith in humans in the sense that they will finally fix the environmental challenges that they face nowadays" and "I believe that in the future humans will manage to live in harmony with nature". In this sense, it firmly believes that a sustainable future and a better quality of life are possible with proper governance institutions and civic participation $(23,33,6$ and 8$)$. However, it is also critical of certain modern technologies for their negative environmental impacts (56). In this respect, unlike the Techno-modernist, it assumes a more cautious position regarding technological fixes and modernist visions associated with economic growth (4).

In relation to its conception of nature, it also assumes the ontological existence of the society-nature divide as this discourse positively values the following statement: "There are two different systems: the socio-cultural and the biophysical" and negatively values: "Nature is a relational continuum between human beings and non-human beings, such as animals, plants, mountains, etc". In this regard, it acknowledges the importance of nature for human 
This is an Accepted Manuscript of the article Latorre, S., \& Malo-Larrea, A. (2019). Policy-making Related Actors' Understandings About Nature-society Relationship: Beyond Modern Ontologies? The Case of Cuenca, Ecuador. Ecological Economics, 156, 387-396., available online

at:https://doi.org/10.1016/j.ecolecon.2018.10.017

(C)2018. This manuscript version is made available under the CC-BY-NC-ND 4.0 license.

wellbeing, and therefore, it gives instrumental reasons to conserve it (32, and 90). Complementing this instrumental value of nature, this discourse recognizes that nature can also have intrinsic value but at the same time it rejects the sacredness of nature (92 and 15). Like Pessimist and Nostalgic Discourses, it assumes for humans a stewardship role over nature.

\section{Urban-Rural relationship}

The Optimist Discourse perception has a more balanced view regarding both urban and rural spheres than the Techno-modernist Discourse has (16, 40, 7, and 20). In fact, it acknowledges the multifunctionality of rural areas and the key role that they will play in the future. This is illustrated by the following statements: total agreement with "Rural areas will play a key role in the future to achieve a more balanced territorial distribution between rural and urban areas" and disagreement with: "Rural areas are only valuable as providers of foodstuffs for urban areas" and "Urban lifestyle and values mean progress and prosperity". In the same line, it considers that rural inhabitants have developed more environmental consciousness and practices than their urban counterparts $(83,75$, and 46$)$. Whereas rural inhabitants derive their environmental consciousness from their direct dependence on nature for securing their livelihoods (material-economic value), urban inhabitants value nature mainly for its aesthetic and recreational value. (48, 52 and 83). Moreover, this discourse allocates equal responsibility for nature conservation to both rural and urban inhabitants (54). In the same line, it values equally both traditional knowledge associated with rural inhabitants and scientific knowledge for advancing more sustainable futures (17).

As it was previously mentioned, the Buen Vivir discourse is not homogenous as it has three main discursive coalitions (the indigenist-pachamamist", the "ecologist-postdevelopmentalist" and the "socialist-statist" coalitions) that in relation to the human-nature relationship aim to transcend the nature-society dualism by promoting more relational ontologies. For that task, all of them appeal to the Andean indigenous cosmologies (which is 
This is an Accepted Manuscript of the article Latorre, S., \& Malo-Larrea, A. (2019). Policy-making Related Actors' Understandings About Nature-society Relationship: Beyond Modern Ontologies? The Case of Cuenca, Ecuador. Ecological Economics, 156, 387-396., available online

at:https://doi.org/10.1016/j.ecolecon.2018.10.017

(C2018. This manuscript version is made available under the CC-BY-NC-ND 4.0 license.

emphasized by the first of the aforementioned coalitions), specially their Pachamamic or Mother Earth view ${ }^{4}$.

This view adopts a holistic and mutualistic perspective in which human nature and nonhuman nature are interrelated and interdependent in a dynamic, harmonious equilibrium (Estermann, 1998). In this perspective, everything is alive and related, in the sense that there is a community (Nature) constituted by networked elements that explain life. Hence, humans are considered only as a small part of Nature. In turn, Nature is considered a source of life (Mother Earth or Pacha Mama) that provides humans with everything they need if they act in a reciprocal way (Lozada, 2007; Cachiguango, 2008; Huanacuni, 2010). Therefore, Pacha Mama is a living subject that requires care and nurturing actions from humans. In this point, the "indigenist-pachamamist" coalition goes further and claims that Pacha Mama is sacred. This hallowing makes humans connect spiritually with her, renewing and reinforcing the link through rituals (Chuji, 2010; Kowi, 2009; Macas, 2011). In sum, Buen Vivir relational ontologies adopt a biocentric perspective in which humans are only one element of a bigger community of interrelated elements. In consequence, humans are not any more at the center of this networked community, rather being subsumed to it as part of Nature and life caregivers instead of external subjects and masters of it. This reciprocal behavior in humans and non-humans also has a spatial dimension reflected in mutual and beneficial relationships between urban and rural areas. Finally, in the search of a harmonious relationship with Nature, scientific rationality loses its "monopoly" and other ways of knowing are valued promoting in this way a "dialogue of knowledges" (Alianza Pais, 2006).

If we compare the Buen Vivir discourse's conception of the nature-society relationship with the four discourses found in Cuenca, it is seen that with the exception of the TechnoModernist discourse, the rest of them acknowledge the dependence of humans on Nature for their wellbeing and the need to adopt stewarding attitudes over Nature. However, the

\footnotetext{
"In relation to the "socialist-statist" coalition, we are focusing on its Buen Vivir discourse developed during the 2006-2009 period when the Buen Vivir conceptual development and the State overhaul took place. Hereafter, its policies and plans show a clear distance with its own previous conceptual vision. It is important to say that this coalition as well as the "ecologist-post-developmentalist" one also incorporate elements of western ecological perspectives to advance these relational ontologies such deep ecology and some strands of ecofeminism.
} 
This is an Accepted Manuscript of the article Latorre, S., \& Malo-Larrea, A. (2019). Policy-making Related Actors' Understandings About Nature-society Relationship: Beyond Modern Ontologies? The Case of Cuenca, Ecuador. Ecological Economics, 156, 387-396., available online

at:https://doi.org/10.1016/j.ecolecon.2018.10.017

(C)2018. This manuscript version is made available under the CC-BY-NC-ND 4.0 license.

perspective of seeing Nature as constituted by living subjects with whom it engages in reciprocal relations to maintain the equilibrium of life (harmony) is not present. Neither there is a view of Nature as sacred in which humans have spiritual and affective connections with it. In this respect, the four discourses identified here are more closely related to those existing in contemporary discourses of the green political economy (Stevenson, 2015), particularly with the diverse approaches within the Sustainable Development (SD) discourse (Hopwood et al., 2005). The Techno-Modernist discourse has a close relationship with that of ecological modernization as it holds an optimistic faith in technology and science to overcome the human dependency on Nature. Moreover, urban society is valued as universally desirable and seen as progressive and modern. In contrast, the main source of environmental degradation is assigned to backward rural areas whose inhabitants lack the knowledge, technology and resources to avoid degradation. The rest of the discourses acknowledge the dependency of humans on the environment to meet their needs and secure their wellbeing in a much wider sense than exploiting nature, as the SD discourse does. However, neither of them transcends the human-nature divide, and instrumental values predominate in their ideas about how to conserve nature. The four discourses see nature exclusively as pristine in sharp contrast to society and therefore also to urban areas. This is important as the process of urbanization of Nature in Ecuador is likely to increase over the coming years, which in turn, may reinforce both divides: society-nature and rural-urban. In this sense, none of these discourses constitutes a radical alternative to the existing views within the debate about sustainability that is framed in the very language of modernity.

\section{Conclusions}

This article has examined the understanding of policy-making related stakeholders in regard to the society-nature relationship in the Ecuadorian city of Cuenca. The aim was to assess whether these understandings differ from or are in tune with more relational ontologies as it is emphasized by the discourse of Buen Vivir. 
This is an Accepted Manuscript of the article Latorre, S., \& Malo-Larrea, A. (2019). Policy-making Related Actors' Understandings About Nature-society Relationship: Beyond Modern Ontologies? The Case of Cuenca, Ecuador. Ecological Economics, 156, 387-396., available online

at:https://doi.org/10.1016/j.ecolecon.2018.10.017

(C2018. This manuscript version is made available under the CC-BY-NC-ND 4.0 license.

The Ecuadorian discourse of Buen Vivir was positioned as an alternative to the variety of developmental discourses, including the currently hegemonic "sustainable development" discourse (SD) of the international environmental governance. Despite many resemblances with the SD discourse, as Vanhulst and Beling (2014) show, it mainly differentiates itself as looking at the relationship between humans and nature in an a-modern or relational ontology that encourages people to think in terms of associations rather than separations. As such, in the "Buen Vivir" discourse, the Eurocentric Cartesian worldview dominant in the sustainability debate, has been identified as one of the main reasons that explains the actual global environmental and social crisis. In this way, some social actors supporting this radical discourse have been promoting a new language such as "Pacha Mama" or Mother Earth, and a new conception of nature as a political subject with rights (rather than an object to be subordinated to humans).

We have claimed the importance of assessing policy-making related stake-holders' views about nature-society as they offer insights on public attitudes and policy making practices with respect to more radical, sustainable futures. In this regard, these views raise the question of whether or not dominant existing cognitive and cultural templates of Ecuadorian society are being destabilized by discourses such as the modern society-nature dualism. This study has shown that rather than disappearing, this dichotomy is deeply rooted in the Ecuadorian policy-related inhabitants. An interpretation of these results in Foucaultian terms indicates that the subjective production power of the Buen Vivir discourse is not having successful results. Policy-related inhabitants' subjectivities in relation to visions on the nature-society relationship are more closely related to the sustainable development discourse that that of the Buen Vivir. Furthermore, it has been shown that the Techno-Modernist discourse is the predominant one among them, being the only one that adopts a view of humans as masters of Nature and an undervaluation position of the need to protect Nature as modern science and technology will fix any ecological problem might appear. In the Ecuadorian case, the modern discourse of natural resources to be exploited might be the hegemonic one in planning and policy-making arenas as in other parts of the world. In this respect, taking into consideration the power of discourses in constructing "reality", we can expect very limited sustainable 
This is an Accepted Manuscript of the article Latorre, S., \& Malo-Larrea, A. (2019). Policy-making Related Actors' Understandings About Nature-society Relationship: Beyond Modern Ontologies? The Case of Cuenca, Ecuador. Ecological Economics, 156, 387-396., available online

at:https://doi.org/10.1016/j.ecolecon.2018.10.017

(02018. This manuscript version is made available under the CC-BY-NC-ND 4.0 license.

policy actions in Cuenca and in Ecuadorian urban contexts generally. The claims that affirm the decolonial and emancipative potential of peripheral inhabitants' worldviews, such as those of Ecuador, should then be taken in a cautious way. It is important to highlight that there might be other social perspectives more in tune with that of the Buen Vivir in other Ecuadorian contexts and social groups, mainly in rural and indigenous areas. This is the main limitation of this research that forces caution in widely generalizing these results to the rest of the country. However, this case study can be seen as a typical case of most Ecuadorian cities. Finally, in relation to the politics of meaning (and Nature), it can be affirmed that at least in Ecuadorian urban contexts, the eco-modernization discourse is wining the discourse battle. This can be explained taking into consideration the powerful social actors and institutions that are promoting it in global environmental governance.

\section{Acknowledgments}

The authors wish to express their sincere gratitude to Unai Villalba-Eguiluz and Teodoro Bustamante, and to the anonymous reviewers of this text for very valuable comments on written versions. Errors, oversights and limitations remain, of course, our own responsibility. The second author acknowledges support from The National Secretariat for Higher Education, Science, Technology and Innovation (SENESCYT), Ecuador. Scholarship programme $\mathrm{N}^{\circ} 127-2012$. 
This is an Accepted Manuscript of the article Latorre, S., \& Malo-Larrea, A. (2019). Policy-making Related Actors' Understandings About Nature-society Relationship: Beyond Modern Ontologies? The Case of Cuenca, Ecuador. Ecological Economics, 156, 387-396., available online

at:https://doi.org/10.1016/j.ecolecon.2018.10.017

(C2018. This manuscript version is made available under the CC-BY-NC-ND 4.0 license.

\section{References}

Acosta, A., (2010). El Buen Vivir en el camino del post-desarrollo: Una lectura desde la Constitución de Montecristi, Policy Paper. Fundación Friedrich Ebert, Quito, Ecuador.

Acosta, A., (2011). Sólo imaginando otros mundos, se cambiará éste. Reflexiones sobre el Buen Vivir, in: Farah, I., Luciano, V. (Eds.), Vivir bien: ¿Paradigma no capitalista? CIDES-UMSA, La Paz, Bolivia, pp. 189-208.

Acosta, A., (2013). El Buen Vivir: Sumak Kawsay, una oportunidad para imaginar otro mundo. Icaria.

Adger, W. N., Benjaminsen, T. A., Brown, K., \& Svarstad, H. (2001). Advancing a political ecology of global environmental discourses. Development and Change, 32, 681-715.

Alcaldía de Cuenca. (2012), "División del Territorio del Cantón Cuenca", available at: http://www.cuenca.gov.ec/?q=page_divisionterritorio (accessed 16 March 2012).

Alianza País. (2006). Plan de Gobierno 2007-2011: un primer gran paso para la trasformación radical del Ecuador.

Altmann, P. (2013), "Good Life As a Social Movement Proposal for Natural Resource Use: The Indigenous Movement in Ecuador", Consilience-The Journal of Sustainable Development, pp. 59-71.

Arsel, M. (2012), 'Between 'Marx and markets'? the state, the 'left turn' and nature in Ecuador", Tijdschrift Voor Economische En Sociale Geografie, Vol. 103 No. 2, pp. $150-163$.

Artiga, R. (2008), "El agua y el medio ambiente en Cuenca, Ecuador", in Moscoso, J., Stewart, O. and Egocheaga, L. (Eds.), El Agua como Recurso Sustentable y de uso múltiple: Políticas para su utilización en zonas urbanas y periurbanas de América Latina y El Caribe, Centro Latinoamericano para el Desarrollo Rural, Santiago de Chile, Chile, pp. 115-131.

Barnett, A. (1988), “Rio Mazan-A People's Forest”, The Ecologist, Vol. 18 No. 2/3, p. 80.

Barry, J., \& Proops, J. (1999). Seeking sustainability discourses with Q methodology. Ecological Economics, 28, 337-345.

Bird, E. A. R. (1987) The Social Construction of Nature: Theoretical Approaches to the History of Environmental Problems, Environmental Review, 11, pp. 255-264.

Breton, V., Cortéz, D. and García S., F. (2014), "En busca del Sumak Kawsay: Presentación del dossier (Dossier)”, Revista Iconos, Vol. 48, pp. 9-24. 
This is an Accepted Manuscript of the article Latorre, S., \& Malo-Larrea, A. (2019). Policy-making Related Actors' Understandings About Nature-society Relationship: Beyond Modern Ontologies? The Case of Cuenca, Ecuador. Ecological Economics, 156, 387-396., available online

at:https://doi.org/10.1016/j.ecolecon.2018.10.017

(C2018. This manuscript version is made available under the CC-BY-NC-ND 4.0 license.

Brown, S. (1980), Political Subjectivity: Applications of Q Methodology in Political Science, Yale University Press, USA.

Brown, S. (1993), “A Primer on Q Methodology”, Operant Subjectlvlty, Vol. 16 No. 3/4, pp. 91-138.

Brown, S. (1998), "The History and Principles of Q Methodology in Psychology and the Social Sciences", available at: http://facstaff.uww.edu/cottlec/QArchive/Bps.htm (accessed 20 March 2012).

Cachiguango, L. E. (2008). Descolonizando la ciencia occidental desde los Andes. Cuadernos de Investigación y Capacitación en Sabiduría y Espiritualidad AndinaAmazónica. Quito (Ecuador): Instituto para el Estudio de la Cultura y Tecnología Andina (IECTA). Colección Kuri-Muyu 3.

Castree, N. (2001), "Socializing nature: theory, practice, and politics", in Castree, N. and Braun, B. (Eds.), Social Nature: Theory, Practice and Politics, Wiley, pp. 1-21.

Castree, N. and Braun, B. (2001), "Preface", in Castree, N. and Braun, B. (Eds.), Social Nature: Theory, Practice and Politics, Wiley, pp. XI-XIV.

Castree, N. and T. MacMillan. (2001), "Dissolving Dualisms: Actor-networks and the Reimagination of Nature", in Castree, N. and Braun, B. (Eds.), Social Nature: Theory, Practice and Politics, Wiley, pp.208-224.

Chuji, M. (2010). El Sumak Kawsay: una opción de vida (Sumak Kawsay versus desarrollo). Ponencia en el VI Encuentro de la Coordinadora Asturiana de ONGD, Oviedo (España). 4 al 6 de noviembre.

Connelly, S. (2007). Mapping sustainable development as a contested concept. Local Environment, 12(3), 259-278.

Cortez, David (2011) La construcción social del "Buen Vivir" (sumak kawsay) en Ecuador. Genealogía del diseño y gestión política de la vida. Aportes Andinos, 28. Quito: Universidad Andina Simón Bolívar, Sede Ecuador; Programa Andino de Derechos Humanos.

Cortez, David (2014) 'Genealogía del sumak kawsay y el buen vivir en Ecuador: un balance'. In Gustavo Endara (coord) Post-Crecimiento y Buen Vivir. Propuestas globales para la construcción de sociedades equitativas y sustentables. Friedrich-Ebert-Stiftung (FES): Quito

Cronon, W. (Ed.) (1995) Uncommon Ground: Toward Reinventing Nature (London: W.W. Norton Company). 
This is an Accepted Manuscript of the article Latorre, S., \& Malo-Larrea, A. (2019). Policy-making Related Actors' Understandings About Nature-society Relationship: Beyond Modern Ontologies? The Case of Cuenca, Ecuador. Ecological Economics, 156, 387-396., available online

at:https://doi.org/10.1016/j.ecolecon.2018.10.017

(C2018. This manuscript version is made available under the CC-BY-NC-ND 4.0 license.

Curry, P. 2003. Re-Thinking Nature: Towards an Eco-Pluralism. Environmental Values 12: $337-60$

Death, Carl (2015) Four discourses of the green economy in the global South, Third World Quarterly, 36:12, 2207-2224, DOI: 10.1080/01436597.2015.1068110

Dingler, Johannes (2005) The discursive nature of nature: Towards a postmodern concept of nature, Journal of Environmental Policy \& Planning, 7:3, 209-225, DOI: $10.1080 / 15239080500339679$

Dryzek, J. S. (1997, 2005, 2013). The politics of the earth (1st, 2nd, 3rd ed.). Oxford, MA: Oxford University Press.

Escobar, A. (1995), Encountering Development: The Making and Unmaking of the Third World, Princeton University Press.

Escobar, A. (2015), "Degrowth, postdevelopment, and trans-itions: a preliminary conversation”, Sustainability Science, Vol. 10 No. 3, pp. 451-462.

Escobar, A. 1996. Construction nature: Elements for a post-structuralist political ecology. Futures 28 (4):325-343.

Estermann, J. (1998). Filosofía Andina, estudio intercultural de la sabiduría autóctona andina. Quito (Ecuador): Ediciones Abya-Yala.

Esteva, G. and Prakash, M.S. (1998), “Beyond Development, What?", Development in Practice, Vol. 8 No. 3, pp. 280-296.

Faccer, Kristy, Anton Nahman \& Michelle Audouin (2014) Interpreting the green economy: Emerging discourses and their considerations for the Global South, Development Southern Africa, 31:5, 642-657, DOI: 10.1080/0376835X.2014.933700

Feindt, Peter H \& Angela Oels (2005) Does discourse matter? Discourse analysis in environmental policy making, Journal of Environmental Policy \& Planning, 7:3, 161173, DOI: $10.1080 / 15239080500339638$

Ferguson, P. (2015). The green economy agenda: Business as usual or transformational discourse? Environmental Politics, 24(1),17-37.

Given, L. (2008), The SAGE Encyclopedia of Qualitative Research Methods, SAGE Publications, Inc., 2455 Teller Road, Thousand Oaks California 91320 United States, available at: http://methods.sagepub.com/reference/sage-encyc-qualitative-researchmethods (accessed 4 July 2016). 
This is an Accepted Manuscript of the article Latorre, S., \& Malo-Larrea, A. (2019). Policy-making Related Actors' Understandings About Nature-society Relationship: Beyond Modern Ontologies? The Case of Cuenca, Ecuador. Ecological Economics, 156, 387-396., available online

at:https://doi.org/10.1016/j.ecolecon.2018.10.017

(C2018. This manuscript version is made available under the CC-BY-NC-ND 4.0 license.

Gudynas, E. (2016), "Beyond varieties of development: disputes and alternatives", Third World Quarterly, 37(4): 721-732.

Gudynas, E., (2009). La dimensión ecológica del buen vivir: entre el fantasma de la modernidad y el desafío biocéntrico. OBETS Rev. Cienc. Soc. 49-53.

Gudynas, E., (2011). Buen Vivir: Today’s tomorrow. Development 54, 441-447

Gudynas, E., Acosta, A., (2011). El buen vivir más allá del desarrolo. Qué Hacer-Cent. Estud. Promoc. Desarro. 181, 70-81.

Gudynas, Eduardo (2017): Value, Growth, Development: South American Lessons for a New Ecopolitics, Capitalism Nature Socialism, DOI: 10.1080/10455752.2017.1372502

Hajer, M. and Versteeg, W. (2005), "A decade of discourse analysis of environmental politics: Achievements, challenges, perspectives", Journal of Environmental Policy \& Planning, Vol. 7 No. 3, pp. 175-184.

Hajer, M.A. (1997), The Politics of Environmental Discourse: Ecological Modernization and the Policy Process, Oxford University Press, Oxford, UK.

Hidalgo, F., (2011). Buen vivir, Sumak Kawsay: Aporte contrahegemónico del proceso andino. Utopía Prax. Latinoam. Rev. Int. Filos. Iberoam. Teoría Soc. 16, 85-94.

Hidalgo-Capitán, A.L. and Cubillo-Guevara, D. (2014), "Seis debates abiertos sobre el Sumak Kawsay", Revista Iconos, Vol. 48, pp. 25-40.

Hopwood, B., Mellor, M. and O’Brien, G. (2005), "Sustainable development: mapping different approaches”, Sustainable Development, Vol. 13 No. 1, pp. 38-52.

Huanacuni, F. (2010). Buen Vivir-Vivir Bien. Filosofía, políticas, estrategias y experiencias regionales andinas. La Paz (Bolivia): CAOI.

INEC. (2010a), "Censo Ecuatoriano de Población y Vivienda 2010”, available at: http://www.inec.gob.ec/cpv/index.php?option=com_wrapper\&view=wrapper\&Itemid $=58 \&$ lang=es (accessed 10 February 2012).

INEC. (2010b), “Censo Nacional Económico 2010”, available at: http://www.inec.gob.ec/cpv/index.php?option=com_wrapper \&view=wrapper\&Itemid =58\&lang=es (accessed 10 February 2012).

Jenkins, R. (2012), "Latin America and China-a new dependency?", Third World Quarterly, Vol. 33 No. 7, pp. 1337-1358. 
This is an Accepted Manuscript of the article Latorre, S., \& Malo-Larrea, A. (2019). Policy-making Related Actors' Understandings About Nature-society Relationship: Beyond Modern Ontologies? The Case of Cuenca, Ecuador. Ecological Economics, 156, 387-396., available online

at:https://doi.org/10.1016/j.ecolecon.2018.10.017

(C2018. This manuscript version is made available under the CC-BY-NC-ND 4.0 license.

Kothari, A., F. Demaria and A. Acosta. (2014). Buen Vivir, Degrowth and Ecological Swaraj: Alternatives to sustainable development and the Green Economy. Development, 57(34), (362-375)

Kowii, A. (2009). El Sumak Kawsay. Aportes Andinos 28. Programa Andino de Derechos Humanos. Universidad Andina Simón Bolívar.

Kröger, M. and Lalander, R. (2016), "Ethno-territorial rights and the resource extraction boom in Latin America: do constitutions matter?", Third World Quarterly, Vol. 37 No. 4, pp. 682-702.

Latorre, S., Farrell, K.N. and Martínez-Alier, J. (2015), "The commodification of nature and socio-environmental resistance in Ecuador: An inventory of accumulation by dispossession cases, 1980-2013", Ecological Economics, Vol. 116, pp. 58-69

Lélé, Sharachchandra M. (1991). Sustainable development: A critical review. World Development 19 (6): 607-621.

Lozada, B. (2007). Cosmovisión, historia y política en los Andes. La Paz (Bolivia): CIMA Editores.

Lloret, P. (2002), The Watershed Council as a Mechanism for Upstream-Downstream Cooperation: The Case of the Río Machángara, Cuenca, Ecuador, Food and Agriculture Organization of the United Nations, available at: (accessed 22 May 2010).

Macas, L., (2010). Sumak Kawsay: La vida en plenitud. América Latina En Movimiento 452, $14-16$.

Macas, L. (2011). El Sumak Kawsay. En: Weber, G. (coord.) Debates sobre cooperación y modelos de desarrollo. Perspectivas desde la sociedad civil en el Ecuador. Quito (Ecuador): Centro de Investigaciones Ciudad-Observatorio de la Cooperación al Desarrollo en Ecuador, pp., 47-60.

McManus, P. (1996). Contested terrains: Politics, stories and discourses of sustainability. Environmental Politics, 5(1), 48-73. doi:10.1080/09644019608414247

Mels, T. (2009). Analysing Environmental Discourses and Representations. In A Companion to Environmental Geography (eds N. Castree, D. Demeritt, D. Liverman and B. Rhoads). doi:10.1002/9781444305722.ch23

Monni, S., Pallottino, M., (2015). Beyond growth and development: buen vivir as an alternative to current paradigms. International Journal of Environmental Policy Making 1, 184-204. 
This is an Accepted Manuscript of the article Latorre, S., \& Malo-Larrea, A. (2019). Policy-making Related Actors' Understandings About Nature-society Relationship: Beyond Modern Ontologies? The Case of Cuenca, Ecuador. Ecological Economics, 156, 387-396., available online

at:https://doi.org/10.1016/j.ecolecon.2018.10.017

(C)2018. This manuscript version is made available under the CC-BY-NC-ND 4.0 license.

Nygren, A. (1998). Environment as Discourse: Searching for Sustainable Development in Costa Rica. Environmental Values 7: 201-22

O'Riordan T. (1989). The challenge of environmentalism. In New Models in Geography, Peet R, Thrift N (eds). Unwin Hyman: London; 77-104.

Osses, F. (2009), Consumer Attitudes towards Food Safety Labelling Information in the UK an Application of Q-Methodology, Master Thesis, University of Edinburgh, Edinburgh, $\mathrm{UK}$.

Purcell, Thomas F., Nora Fernandez, and Estefania Martinez. (2016). 'Rents, Knowledge and Neo-Structuralism: Transforming the Productive Matrix in Ecuador'. Third World Quarterly, 26: 1-21

Radcliffe, S.A., (2012). Development for a postneoliberal era? Sumak kawsay, living well and the limits to decolonisation in Ecuador. Geoforum 43, 240-249.

Ramírez, R., (2010). Socialismo del Sumak Kawsay o biosocialismo republicano, Documentos de Trabajo. SENPLADES, Quito, Ecuador.

Rydin, I. (1999). Can We Talk Ourselves into Sustainability? The Role of Discourse in the Environmental Policy Process. Environmental Values 8: 467-484

Stevenson, H. (2015), “Contemporary Discourses of Green Political Economy: A Q Method Analysis”, Journal of Environmental Policy \& Planning, pp. 1-21

Van den Brink, M., and T. Metze. (2006). "Words matter in policy and planning". In: Van den Brink, M., and T. Metze (Eds). Words matter in policy and planning. Discourse theory and method in the social science. Pp. 13-20. Netherlands Geographical Studies 344.

Vanhulst, J. and Beling, A. (2014), "Buen vivir: la irrupción de América Latina en el campo gravitacional del desarrollo sostenible", Revista Iberoamericana de Economía Ecológica, Vol. 21, pp. 1-14.

Vanhulst, J., (2015). El laberinto de los discursos del Buen vivir: entre Sumak Kawsay y Socialismo del siglo XXI. Polis Rev. Latinoam. 14, 1-21.

Villalba, U. (2013), "Buen Vivir vs Development: a paradigm shift in the Andes?", Third World Quarterly, Vol. 34 No. 8, pp. 1427-1442.

Villalba-Eguiluz and Etxano, I. (2017). "Buen Vivir vs Development (II): the limits of (neo)extractivism. Ecological Economics 138:1-11. 
This is an Accepted Manuscript of the article Latorre, S., \& Malo-Larrea, A. (2019). Policy-making Related Actors' Understandings About Nature-society Relationship: Beyond Modern Ontologies? The Case of Cuenca, Ecuador. Ecological Economics, 156, 387-396., available online

at:https://doi.org/10.1016/j.ecolecon.2018.10.017

(C2018. This manuscript version is made available under the CC-BY-NC-ND 4.0 license.

Viola, A., (2011). Desarrollo, bienestar e identidad cultural: del desarrollismo etnocida al Sumak Kawsay en los Andes, in: Palenzuela, P., Olivi, A. (Eds.), Etnicidad y desarrollo en los Andes. Universidad de Sevilla, Sevilla, España, pp. 255-302

Walsh, C., (2010). Development as Buen Vivir: Institutional arrangements and (de)colonial entanglements. Development 53, 15-21.

Ziai, A. (2007), "Development discourse and its Critics. An introduction to postdevelopment", Exploring Post-Development: Theory and Practice, Problems and Perspectives, Taylor \& Francis, pp. 3-17.

Zografos, C. (2007), "Rurality discourses and the role of the social enterprise in regenerating rural Scotland”, Journal of Rural Studies, Vol. 23 No. 1, pp. 38-51 